\title{
Experimental verification of formed of the personal component of the readiness medical students for professional activity
}

\author{
Shevchenko L. S., lliasova Yu. S. \\ Vinnytsia Mykhailo Kotsiubynsky State Pedagogical University, Vinnytsia, Ukraine
}

Received: 12.06.2019 Accepted: 22.12.2020

\begin{abstract}
The results of the formative stage of the experiment have been analyzed. Comparative characterization of the experimental groups and control groups has been presented. At the primary stage of researching an insufficient level of readiness of junior medical staff was determined. The research was conducted in 2017-2019 years. The empirical basis at the formative stage of the study included 247 students and 70 teachers of professional disciplines at medical colledges of Vinnytsia region: Vinnytsia medical college named after D.K. Zabolotny, Bershad medical college, Haisyn medical college, Mohyliv-Podilsky medical college and Pohrebyshche medical college. At the formative stage of the experiment students of the control groups studied according to traditional methods, and their teachers of professional disciplines used traditional teaching technologies: educational blogs, mental maps, online exercises LearningApps. Students of the experimental groups studied according to innovative methods, and their teachers used Internet technologies. The experimental verification of the effectiveness of the introduction of the pedagogical conditions: contextual learning technologies, methods of forming deontological competence and innovative Internet technologies on the training of future junior medical staff in study of special disciplines is presented. It was determined that during the pedagogical experiment there were significant changes in personal component of readiness. It was specified that future junior medical staff of the experimental groups at the formative stage of the experiment received better results, than the students of the control groups. Prospects for further researching are perceived in creation of teaching and methodological support for the formation of readiness of future medical staff to their professional activity by means of modern technologies at the studying of others disciplines in medical schools.
\end{abstract}

Key words: future medical staff, special disciplines, the formative stage of the experiment.

\section{Експериментальна перевірка сформованості особистісного компоненту готовності студентів-медиків до професійної діяльності}

\author{
Шевченко Л. С., Ілясова Ю. С.
}

Вінницький державний педагогічний університет імені Михайла Коцюбинського, м. Вінниця, Україна

\begin{abstract}
Анотація. У статті подано результати проведеного формувального етапу експерименту. У процесі дослідноекспериментальної роботи експериментально перевірено ефективність розробленої методики та методичного забезпечення професійної підготовки студентів медичних коледжів на основі розробленої моделі та виокремлених педагогічних умов. Описано результати дослідження, яке проводилося в 2017-2019 роках серед викладачів і студентів Вінницького медичного коледжу імені Д.К. Заболотного, Бершадського, Гайсинського, Могилів-Подільського та Погребищенського медичних коледжів. У статті продемонстровано результати формувального етапу експерименту під час перевірки сформованості особистісного компоненту готовності студентів-медиків до професійної діяльності. На фрормувальному етапі експерименту ми мали за мету впровадити в освітній процес медичних коледжів технологію контекстного навчання у вивченні фахових дисциплін; сформувати у студентів експериментальних груп (ЕГ) деонтологічну компетентність та ознайомити і навчити викладачів, які викладали фахові дисципліни в ЕГ, користуватися інноваційними інтернеттехнологіями, а саме освітнім блогом платформи Blogger, ментальними картами онлайн-сервісу Mindomo та ігровими вправами сервісу LearningApps, а також впровадити їх в освітній процес з метою вивчення фахових дисциплін. Студенти контрольних груп (КГ) вивчали фахові дисципліни за традиційними методиками. Визначено, що під час проведення педагогічного експерименту відбулися значні зміни за особистісним компонентом. Доведено, що студенти експериментальних груп на формувальному етапі експерименту
\end{abstract}

Corresponding Author: lliasova Yuliia Stanislavivna. Tel. 0973326630 .E-mail: iyulya72@ukr.net Vinnytsia Medical Colledge, Pirogova St., 57,Vinnytsia, Ukraine, 21000.

Відповідальний автор: Ілясова Юлія Станіславівна. Тел. 0973326630. E-mail: iyulya72@ukr.net Вінницький медичний коледж, вул. Пирогова, 57, м. Вінниця, 21000. 
одержали більш високі результати в порівнянні зі студентами контрольних груп, і відповідно мають вищий рівень сформованої готовності до професійної діяльності. Вважаємо, що наші доробки в контексті використання технології контекстного навчання, формування деонтологічної компетентності й застосування інноваційних інтернет-технологій можна використовувати під час вивчення інших дисциплін у сучасних медичних закладах вищої та фахової передвищої освіти.

Ключові слова: майбутні молодші медичні спеціалісти; формувальний етап експерименту; фахові дисципліни.

\title{
Экспериментальная проверка сформированности личностного компонента готовности студентов-медиков к профессиональной деятельности
}

\author{
Шевченко Л. С., Ілясова Ю. С.
}

Винницкий государственный педагогический университет имени Михаила Коцюбинського, г. Винница, Украина

\begin{abstract}
Аннотация. В статье поданы результаты проведенного формирующего этапа эксперимента. В процессе опытно-экспериментальной работы проверена эффективность инновационного методического обеспечения профессиональной подготовки студентов медицинских колледжей на основе разработанной модели и выделенных педагогических условий. Описаны результаты исследования, которое проводилось в 2017-2019 годах среди преподавателей и студентов Винницкого медицинского колледжа имени Д. К. Заболотного, Бершадского, Гайсинского, Могилев-Подольского и Погребищенского медицинских колледжей. В статье мы демонстрируем результаты формирующего этапа эксперимента во время проверки формирования личностного компонента готовности студентов-медиков к профессиональной деятельности. На формирующем этапе эксперимента мы использовали в образовательном процессе медицинских колледжей технологию контекстного обучения при изучении профессиональных клинических дисциплин; формировали у студентов экспериментальных групп (ЕГ) деонтологическую компетентность и ознакомили и научили преподавателей профессиональных дисциплин в ЕГ пользоваться инновационными интернет-технологиями, а именно образовательным блогом платформы Blogger, ментальными картами онлайн-сервиса Mindomo и игровыми упражнениями сервиса LearningApps, а также внедрили их в образовательный процесс с целью изучения профессиональных дисциплин. Определено, что во время проведения педагогического эксперимента состоялись значительные изменения личностного компонента готовности студентов-медиков к профессиональной деятельности. Доказано, что студенты экспериментальных групп на формирующем этапе эксперимента получили лучшие результаты по сравнению со студентами контрольных групп, и соответственно имеют более высокий уровень сформированной готовности к профессиональной деятельности. Считаем, что наши разработки в контексте использования технологии контекстного обучения, формирования деонтологической компетентности и применения инновационных интернет-технологий можно использовать во время изучения других дисциплин в современных медицинских учебных заведениях.

Ключевые слова: будущие младшие медицинские специалисты; формирующий этап эксперимента; профессиональные дисциплины.
\end{abstract}

\section{Bcmyn}

В зв'язку з впровадженням низки реформ у сучасній медичній освіті, в умовах швидкого інноваційного розвитку як української освіти так і всього суспільства, загострилася проблема підготовки майбутніх медиків до професійної діяльності. Нині розвиток сучасної освіти не встигає за прогресуючими з кожним днем світовими інноваціями в науці та практиці. Суть проблеми полягає в тому, що з кожним днем кількість нової інформації збільшується, постійно з'являються нові погляди та теорії на ту чи іншу проблему, і традиційне вивчення нових підходів та технологій в рамках аудиторних занять вже не може забезпечити ефективну трансформацію набутих науково-клінічних знань, вмінь та навичок у студентів під час навчання для реалізації їх у майбутній професійній діяльності.

У сучасному інформаційному суспільстві майбутнім медикам потрібно мати не тільки достатній запас знань із фундаментальних і клінічних дисциплін, але й бути творчими та креативними, здатними швидко адаптуватися в різних життєвих ситуаціях, самостійно набувати необхідні знання, вміло їх застосовувати в практичній діяльності та оптимально будувати своє майбутнє в швидкопрогресуючому інформаційному просторі.

Реформування української медичної освіти в умовах сьогодення напряму пов'язане з усіма ланками медичних працівників. Актуальність «розвитку медичної освіти в сучасних умовах 
віддзеркалюється законодавством України, що регламентує сферу вищої освіти України згідно законам України «Про освіту», «Про вищу освіту», Указу Президента України від 25 червня 2013 року № 344/2013 «Про Національну стратегію розвитку освіти в Україні на період до 2021 року» [1]. Згідно вказаним законодавчим документам починати реформаторські зміни в медицині необхідно насамперед із категорії тих медичних працівників, які більше часу, ніж інші, проводять із пацієнтами, $\epsilon$ безпосередньою зв'язуючою ланкою між лікарями та хворими, саме з професійної підготовки майбутніх молодших медичних спеціалістів.

Останніми роками спостерігається підвищення інтересу вітчизняних і зарубіжних науковців до вдосконалення процесу профресійної підготовки студентів-медиків у процесі вивчення фрахових дисциплін. Накопичено значний досвід використання активних методів і технологій під час вивчення клінічних дисциплін у медичних закладах вищої освіти (3ВО) (У. Батюшкіна, О. Борлуцька, Л. Булат, Н. Дідик, Т. Колда, Г. Краснова, С. Лембрик, О. Лисунець, Л. Раковська, Л. Русаневич, У. Уестон, О. Хомко й ін.); упровадження й ефрективного застосування засобів інформаційно-комунікаційних технологій (IKT) (С. Бондар, О. Бондаренко, Л. Гармаш, С. Дмитренко, Н. Заічко, О. Качула, С. Ладутько, О. Пічкур, О. Тертишна, Д. Фільчуков, О. Штатько й ін.); визначення ролі інтеграції фахових дисциплін у медичних закладах освіти (Л. Аукенова, Г. Афанасьєва, В. Безрук, Т. Безрук, 3. Гусеінова, С. Кабиєва, Т. Колда, Є. Корнєєва, В. Курилова, М.Мандибаєва, .М. Пайкуш, $€$. Пономарьова, А. Ребров, Л. Русаневич, Д. Тайжанова, А. Толеуова, Г. Хусаїнова й ін.); особливостей викладання фахових дисциплін у професійній підготовці майбутніх медиків $(€$. Дробязгин, $Є$. Івлієва, Н. Лобанець, І. Марків, І. Мерецька, Є. Песоцька, А. Полякевич, І. Поршенніков, І. Радзієвська, О. Самогальська, С. Стефанко, В. Тюріна, Р. Хурса, Ю. Чикинєв та ін.).

Головною умовою для покращення професійної підготовки майбутніх медиків під час навчання в медичних закладах освіти має бути створення такої освітньої системи, яка поступово переходила від теоретичних аспектів навчання до об'єкту безпосередньої фахової діяльності, зокрема відображала реальне клінічне середовище, сприяла формуванню нового типу медичного спеціаліста з високим рівнем знань і вмінь, достатнім рівнем інтелекту та наділеним милосердям, добротою, терпінням, людяністю і співчуттям, і була оптимізована до сучасних вимог сьогодення шляхом впровадження ІКТ. У зв'язку з чим у процесі аналізу психологічної, педагогічної, медичної літератури та власного педагогічного досвіду нами визначено й обгрунтовано комплекс педагогічних умов, зокрема створення і моделювання предметного та соціального контексту в студентів-медиків; формування деонтологічної компетентності в процесі професійної підготовки майбутніх молодших медичних спеціалістів; використання інноваційних інтернет-технологій навчання й оцінювання, і розроблена модель професійної підготовки майбутніх молодших медичних спеціалістів у процесі вивчення фахових дисциплін, що містить мотиваційний, когнітивно-діяльнісний та особистісний компоненти. У цій статті ми досліджуємо вплив вищевказаних педагогічних умов на сформованість особистісного компоненту готовності студентів-медиків до професійної діяльності.

Особистісний компонент містить сфрормованість особистісних і професійно-значущих якостей, зокрема емпатії, толерантності, милосердя, людяності, терпіння, доброти, співпереживання до пацієнта, вміння поставити себе на місце хворого, оволодіння знаннями щодо етичних і деонтологічних норм взаємовідносин, а також здатність до рефлексії й адекватної самооцінки. Для оцінювання рівнів сформованості готовності майбутніх медичних молодших спеціалістів до професійної діяльності під час вивчення фахових дисциплін за вказаним компонентом було обрано деонтологічний і рефлексивний критерії. Показниками деонтологічного критерію є: розвиненість особистісних і моральних якостей щодо виконання професійних завдань, дотримання майбутніми медиками основних морально-етичних правил і норм поведінки. Показниками рефрлексивного критерію є: вміння здійснювати рефлексію, здатність до саморегуляції, самореалізації та саморозвитку; володіння навичками самоосвіти; сфоорованість потреби в самодосконаленні; вміння самооцінки та коригування результатів власної профресійної підготовки.

3 огляду на окреслену проблему, метою статті $\epsilon$ висвітлення основних результатів експериментальної перевірки сформованості особистісного компоненту готовності студентів-медиків до професійної діяльності під час вивчення фахових дисциплін в умовах медичних коледжів. 


\section{II Матеріал і методи дослідження}

У нашому дослідженні ми використовували такі методи як аналіз, синтез, узагальнення та порівняння теоретичних і емпіричних даних, за допомогою яких ми маємо змогу показати практичну апробацію ефективності впровадження вищезазначених педагогічних умов, анкетування студентів щодо ефективності використання вищезгаданих інновацій у процесі професійної підготовки майбутніх медиків під час вивчення фахових дисциплін, узагальнення власного педагогічного досвіду і педагогічний експеримент.

На формувальному етапі експерименту (2017-2018 р.р.) ми мали за мету впровадити в освітній процес медичних закладів освіти технологію контекстного навчання у вивченні фахових дисциплін; сорормувати в студентів експериментальних груп (ЕГ) деонтологічну компетентність, ознайомити та навчити викладачів, які викладали фахові дисципліни в ЕГ, користуватися інноваційними інтернеттехнологіями, а саме освітнім блогом платформи Blogger, ментальними картами онлайн-сервісу Mindomo та ігровими вправами сервісу LearningApps, а також впровадити їх в освітній процес під час вивчення фахових дисциплін. Студенти контрольних груп (КГ) займалися за традиційними методиками, i викладачі в процесі викладання фахових дисциплін використовували традиційні методи та технології, які застосовувалися на констатувальному етапі. На фрормувальному етапі експерименту було задіяно 124 студента контрольних груп («Лікувальна справа» (48 осіб); «Сестринська справа» (43 особи), «Акушерська справа» (33 особи)) та 123 - експериментальних груп («Лікувальна справа» (47 осіб), «Сестринська справа» (43 особи), «Акушерська справа» (33 особи)), а також 70 викладачів фрахових дисциплін Вінницького (42 особи), Погребищенського (7 осіб), Бершадського (6 осіб), МогилівПодільського (8 осіб) та Гайсинського (7 осіб) медичних коледжів, які вже брали участь на констатувальному етапі експерименту. Емпіричну базу склали студенти 3 і 4 курсів.

\section{III Результати}

Аналіз сформованості особистісного компоненту на початку експерименту здійснювався на основі діагностичної методики розвитку рефлексивності А. Карпова [2]; діагностики самооцінки за Л. Кайдаловою [3]; методики визначення соціальної емпатії Н. Фетискина, В. Козлова, Г. Манойлова [4] та методики визначення доброзичливості Кемпбелла [5]. Перевірка проводилася у вересні 2017 року для студентів 4 курсу спеціалізацій «Сестринська справа», «Акушерська справа» та «Лікувальна справа».

Для діагностики рівнів розвитку рефлексивності А. Карпова студентам необхідно було дати відповіді на декілька тверджень опитувальника. Результати дослідження розвитку рефрлексивності А. Карпова показали, що у майбутніх молодших медичних спеціалістів переважає низький і середній рівні розвитку рефлексивності.

В $32(25,81 \%)$ студентів КГ виявлено високий рівень розвитку рефрлективності:

в $44(35,48 \%)$ - середній рівень,

у $48(38,71 \%)$ - низький рівень.

Відповідно, в 26 (21,14\%) студентів ЕГ виявлено високий рівень розвитку рефлективності:

в $50(40,65 \%)$ - середній рівень;

у $47(38,21 \%)$ - низький рівень (табл. 1).

Для визначення рівнів самооцінювання майбутніх молодших медичних спеціалістів на початку експерименту було використано тест діагностики самооцінки за Л. Кайдаловою. Одержані результати діагностики самооцінки показали, що в майбутніх молодших медичних спеціалістів переважає низький і середній рівні самооцінки.

В 5 (4,03\%) студентів КГ виявлено високий рівень самооцінки:

в $67(54,04 \%)$ - середній рівень;

у $52(41,93 \%)$ - низький рівень.

Відповідно, в 9 (7,32\%) студентів ЕГ виявлено високий рівень самооцінки:

в $70(52,85 \%)$ - середній рівень;

у $44(39,83 \%)$ - низький рівень (табл. 2). 
Табл. 1. Середні результати діагностики рефрлексивності студентів КГ та ЕГ на початку експерименту

\begin{tabular}{|l|c|c|c|c|}
\hline \multirow{2}{*}{ Рівні ресрлексивності } & \multicolumn{2}{|c|}{ КГ } & \multicolumn{2}{c|}{ ЕГ } \\
\cline { 2 - 5 } & $\mathrm{n}$ & $\%$ & $\mathrm{n}$ & $\%$ \\
\hline Високий & 32 & 25,81 & 26 & 21,14 \\
\hline Середній & 44 & 35,48 & 50 & 40,65 \\
\hline Низький & 48 & 38,71 & 47 & 38,21 \\
\hline Всього & 124 & 100,00 & 123 & 100,00 \\
\hline
\end{tabular}

Табл. 2. Середні результати діагностики самооцінки студентів КГ та ЕГ на початку експерименту

\begin{tabular}{|l|c|c|c|c|}
\hline \multirow{2}{*}{ Рівні самооцінки } & \multicolumn{2}{|c|}{ КГ } & \multicolumn{2}{c|}{ ЕГ } \\
\cline { 2 - 5 } & $\mathrm{n}$ & $\%$ & $\mathrm{n}$ & $\%$ \\
\hline Високий & 5 & 4,03 & 9 & 7,32 \\
\hline Середній & 67 & 54,04 & 70 & 52,85 \\
\hline Низький & 52 & 41,93 & 44 & 39,83 \\
\hline Всього & 124 & 100 & 123 & 100 \\
\hline
\end{tabular}

Для діагностики рівнів соціальної емпатії майбутні молодші медичні спеціалісти відповідали (погоджуючись чи ні) на кожне з 33 тверджень. У процесі обробки результатів анкетування визначено індивідуальний індекс емпатійності (le) кожного досліджуваного згідно таблиці інтерпретації індексу le 3 урахуванням віку та статі респондентів.

Одержані результати початкової діагностики показали, що в $9(7,26 \%)$ студентів КГ виявлено високий рівень емпатійності:

в $60(48,39 \%)$ - середній рівень,

у $55(44,35 \%)$ - низький рівень емпатійності.

Відповідно в 7 (5,69\%) студентів ЕГ визначено високий рівень емпатійності:

в $62(50,41 \%)$ - середній рівень,

у 54 (43,90\%) - низький рівень емпатійності (табл. 3).

Табл. 3. Середні результати діагностики соціальної емпатії студентів КГ та ЕГ на початку експерименту

\begin{tabular}{|l|c|c|c|c|}
\hline \multirow{2}{*}{ Рівні соціальної емпатії } & \multicolumn{2}{|c|}{ КГ } & \multicolumn{2}{c|}{ ЕГ } \\
\cline { 2 - 5 } & $\mathrm{n}$ & $\%$ & $\mathrm{n}$ & $\%$ \\
\hline Високий & 9 & 7,26 & 7 & 5,69 \\
\hline Середній & 60 & 48,39 & 62 & 50,41 \\
\hline Низький & 55 & 44,35 & 54 & 43,90 \\
\hline Всього & 124 & 100 & 123 & 100 \\
\hline
\end{tabular}

Особливістю професійної діяльності майбутніх молодших медичних спеціалістів $є$ безпосередній прямий контакт із хворим. Саме ця категорія медиків більшість свого робочого часу проводить із пацієнтами, виконує медичні маніпуляції, здійснює догляд і нагляд, спілкується й інше. Саме у взаємосприйманні майбутніх молодших медичних спеціалістів і хворих створюються умови для проявів відчуття симпатії чи антипатії. 
М. Філоненко вважає, що «доброзичливість - це добре, емоційно-позитивне ставлення до пацієнта, особиста зацікавленість і участь у вирішенні його проблем» [6, с. 242]. Підтримуємо думку вченої, що «з огляду на важливість медичної професії, а це підвищені вимоги до спілкування, особливе терпіння, ввічливість, співчуття, поважне і турботливе ставлення до хворої людини, вміння підтримати їі морально, піклуватися про її здоров'я, вкладаючи душу в свою роботу, висуваються підвищені вимоги щодо професійної компетентності й особистісних якостей майбутніх медиків» [6, с. 242].

Отже, для визначення рівня сформованості особистісного компоненту обрано методику «Шкала доброзичливості» Кемпбелла [5, с. 282-283]. Саме доброзичливість $є$ однією з головних професійних особистісних якостей майбутнього молодшого медичного спеціаліста. Ця методика визначає рівень позитивного ставлення до людей, зокрема до пацієнтів, проявів доброти та особистісної зацікавленості в покращенні стану хворого. Студентам-медикам необхідно було прочитати вісім пар тверджень і 3 кожної пари обрати те, що найбільш співпадало з їхньою особистою думкою.

Одержані результати діагностики на початку експерименту показали, що в 14 (10,95\%) студентів КГ визначено високий рівень доброзичливості:

в $85(68,57 \%)$ - середній рівень,

у $25(20,48 \%)$ - низький рівень.

Відповідно в 13 (10,57\%) студентів ЕГ визначено високий рівень доброзичливості:

в $86(69,92 \%)$ - середній рівень,

у $27(21,95 \%)$ - низький рівень (табл. 4).

Табл. 4. Середні результати діагностики доброзичливості студентів КГ та ЕГ на початку експерименту

\begin{tabular}{|l|c|c|c|c|}
\hline \multirow{2}{*}{ Рівні доброзичливості } & \multicolumn{2}{|c|}{ КГ } & \multicolumn{2}{c|}{ ЕГ } \\
\cline { 2 - 5 } & $\mathrm{n}$ & $\%$ & $\mathrm{n}$ & $\%$ \\
\hline Високий & 14 & 10,95 & 10 & 8,13 \\
\hline Середній & 85 & 68,57 & 86 & 69,92 \\
\hline Низький & 25 & 20,48 & 27 & 21,95 \\
\hline Всього & 124 & 100 & 123 & 100 \\
\hline
\end{tabular}

Отже, спостерігаємо недостатній рівень сформованості особистісного компоненту в студентів КГ та ЕГ. Виявлено також низький рівень соціальної емпатії, доброзичливості, рефрлексії та самооцінки в майбутніх медиків. Після впровадження в освітній процес медичних коледжів спеціальних педагогічних умов, зокрема створення і моделювання предметного та соціального контексту в студентів-медиків; формування деонтологічної компетентності в процесі професійної підготовки майбутніх молодших медичних спеціалістів; використання інноваційних інтернет-технологій навчання й оцінювання наприкінці формувального етапу експерименту було проведено діагностику сформованості готовності майбутніх молодших медичних спеціалістів до професійної діяльності за особистісним компонентом. Нами використано діагностичні методики розвитку рефлексивності А. Карпова; самооцінки за Л Кайдаловою; визначення соціальної емпатії Н. Фетискина, В. Козлова, Г. Манойлова та методики визначення доброзичливості Кемпбелла. Прикінцева діагностика проводилася в квітні 2018 року - для студентів спеціалізацій «Сестринська справа» і «Лікувальна справа» та в листопаді 2017 року - для студентів спеціалізацій «Акушерська справа». Було визначено рівні рефрлексивності.

Одержані результати показали (табл. 5), що в 36 (29,03\%) студентів КГ виявлено високий рівень рефлективності:

в $47(37,90 \%)$ - середній рівень,

у $41(33,06 \%)$ - низький рівень рефлексивності.

Відповідно в 41 (33,33\%) студента ЕГ визначено високий рівень рефлективності:

в $47(38,21 \%)$ - середній рівень,

у $35(28,46 \%)$ - низький рівень рефлексивності. 
Табл. 5. Середні результати діагностики рефлексивності студентів КГ та ЕГ наприкінці фрормувального етапу експерименту

\begin{tabular}{|l|c|c|c|c|}
\hline \multirow{2}{*}{ Рівні ресрлексивності } & \multicolumn{2}{|c|}{ КГ } & \multicolumn{2}{c|}{$\mathrm{E}$} \\
\cline { 2 - 5 } & $\mathrm{n}$ & $\%$ & $\mathrm{n}$ & $\%$ \\
\hline Високий & 36 & 29,03 & 41 & 33,33 \\
\hline Середній & 47 & 37,90 & 47 & 38,21 \\
\hline Низький & 41 & 33,07 & 35 & 28,46 \\
\hline Всього & 124 & 100 & 124 & 100 \\
\hline
\end{tabular}

Наступним кроком формувального етапу експерименту було визначення рівнів самооцінки.

Одержані результати показали (табл. 6), що в 11 (8,87\%) студентів КГ виявлено високий рівень самооцінки:

в $71(57,26 \%)$ - середній рівень,

у $42(33,87 \%)$ - низький рівень самооцінки.

Відповідно в 22 (17,89\%) студентів ЕГ визначено високий рівень самооцінки:

в $78(63,41 \%)$ - середній рівень,

у $23(18,7 \%)$ - низький рівень самооцінки.

Табл. 6. Середні результати діагностики самооцінки студентів КГ та ЕГ наприкінці формувального етапу експерименту

\begin{tabular}{|l|c|c|c|c|}
\hline \multirow{2}{*}{ Рівні самооцінки } & \multicolumn{2}{|c|}{ КГ } & \multicolumn{2}{c|}{ ЕГ } \\
\cline { 2 - 5 } & $\mathrm{n}$ & $\%$ & $\mathrm{n}$ & $\%$ \\
\hline Високий & 11 & 8,87 & 22 & 17,89 \\
\hline Середній & 71 & 57,26 & 78 & 63,41 \\
\hline Низький & 42 & 33,87 & 23 & 18,70 \\
\hline Всього & 124 & 100 & 123 & 100 \\
\hline
\end{tabular}

Також наприкінці формувального етапу експерименту було визначено рівні емпатичних тенденцій згідно таблиці інтерпретації індексу lе з урахуванням віку та статі респондентів.

Одержані результати показали (табл. 7), що в 13 (10,48\%) студентів КГ виявлено високий рівень емпатійності:

в $67(54,03 \%)$ - середній рівень,

у $44(35,48 \%)$ - низький рівень.

Відповідно в 27 (21,95\%) студентів ЕГ визначено високий рівень емпатійності:

в $62(50,41 \%)$ - середній рівень,

у $34(27,64 \%)$ - низький рівень.

Також було визначено рівні доброзичливості наприкінці формувального етапу експерименту (табл. 8).

Одержані результати показали, що в 16 (12,9\%) студентів КГ виявлено високий рівень доброзичливості:

в $88(70,97 \%)$ - середній рівень,

у $20(16,13 \%)$ - низький рівень.

Відповідно в 26 студентів ЕГ $(21,14 \%)$ визначено високий рівень доброзичливості:

в $80(65,04 \%)$ - середній рівень,

у $17(13,82 \%)$ - низький рівень. 
Табл. 7. Середні результати діагностики соціальної емпатії студентів КГ та ЕГ наприкінці формувального етапу експерименту

\begin{tabular}{|l|c|c|c|c|}
\hline \multirow{2}{*}{ Рівні } & \multicolumn{2}{|c|}{ КГ } & \multicolumn{2}{c|}{ ЕГпатійності } \\
\cline { 2 - 5 } & $\mathrm{n}$ & $\%$ & $\mathrm{n}$ & $\%$ \\
\hline Високий & 13 & 10,48 & 27 & 21,95 \\
\hline Середній & 67 & 54,03 & 62 & 50,41 \\
\hline Низький & 44 & 35,49 & 34 & 27,64 \\
\hline Всього & 124 & 100 & 123 & 100 \\
\hline
\end{tabular}

Табл. 8. Середні результати діагностики доброзичливості студентів КГ та ЕГ наприкінці формувального етапу експерименту

\begin{tabular}{|l|c|c|c|c|}
\hline \multirow{2}{*}{$\begin{array}{c}\text { Рівень } \\
\text { доброзичливості }\end{array}$} & \multicolumn{2}{|c|}{ КГ } & \multicolumn{2}{c|}{ КГ } \\
\cline { 2 - 5 } & Киськість (n) & $\%$ & Кількість (n) & $\%$ \\
\hline Серекий & 16 & 12,90 & 26 & 21,14 \\
\hline Низький & 88 & 70,97 & 80 & 65,04 \\
\hline Всього & 20 & 16,13 & 17 & 13,82 \\
\hline
\end{tabular}

\section{IV Обговорення}

Вивчення результатів оцінювання ефективності впровадження педагогічних умов відповідно до особистісного компоненту, свідчить про те, що його зростання відбулося за рахунок збільшення в ЕГ кількості студентів із високим рівнем рефлексивності (з 21,14\% до 33,33\%), тобто на 12,19\%, і відповідно зменшення кількості студентів ЕГ із низьким рівнем рефрлексивності з 38,21\% до 28,46\%, тобто на 9,75\%. Кількість студентів із середнім рівнем рефрлексивності після проведеного експерименту збільшилась в ЕГ 40,65\% до 38,21\%, тобто на 2,44\%.

Вивчення результатів оцінювання ефективності впровадження педагогічних умов відповідно до особистісного компоненту, свідчить про те, що його зростання відбулося за рахунок збільшення в ЕГ кількості студентів із високим рівнем самооцінки (з 7,32\% до 17,89\%), тобто на 10,57\%, і відповідно, зменшення кількості студентів ЕГ із низьким рівнем самооцінки з 39,83\% до 18,7\%, тобто на 21,13\%. Кількість студентів із середнім рівнем самооцінки після проведеного експерименту збільшилась в ЕГ із $52,85 \%$ до 63,41\%, тобто на $10,56 \%$.

Вивчення результатів оцінювання ефективності впровадження педагогічних умов відповідно до особистісного компоненту, свідчить про те, що його зростання відбулося за рахунок збільшення в ЕГ кількості студентів із високим рівнем емпатичних тенденцій (із 5,69\% до 21,95\%), тобто на 16,26\%, і відповідно, зменшення кількості студентів ЕГ із низьким рівнем емпатичних тенденцій із 43,90\% до $27,64 \%$, тобто на $16,26 \%$.

Вивчення результатів оцінювання ефрективності впровадження педагогічних умов відповідно до особистісного компоненту, свідчить про те, що його зростання відбулося за рахунок збільшення в ЕГ кількості студентів із високим рівнем доброзичливості (з 8,13\% до 21,14\%), тобто на 13,01\%, і відповідно, зменшення кількості студентів ЕГ із низьким рівнем із 21,95\% до 13,82\%, тобто на 8,13\%. Кількість студентів із середнім рівнем доброзичливості після проведеного експерименту зменшилась в ЕГ із 69,92\% до 65,04\%, тобто на 4,88\%.

Отже, в студентів ЕГ у порівнянні з КГ значно підвищився рівень розвитку рефрлексивності, самооцінки, соціальної емпатії та доброзичливості. Вважаємо, що ці позитивні зміни є результатом 
впровадження педагогічних умов і розробленої моделі профресійної підготовки майбутніх молодших медичних спеціалістів у процесі вивчення фахових дисциплін.

На рис. 1 відображено результати сформованості особистісного компоненту на початку та наприкінці формувального етапу експерименту в КГ та ЕГ.

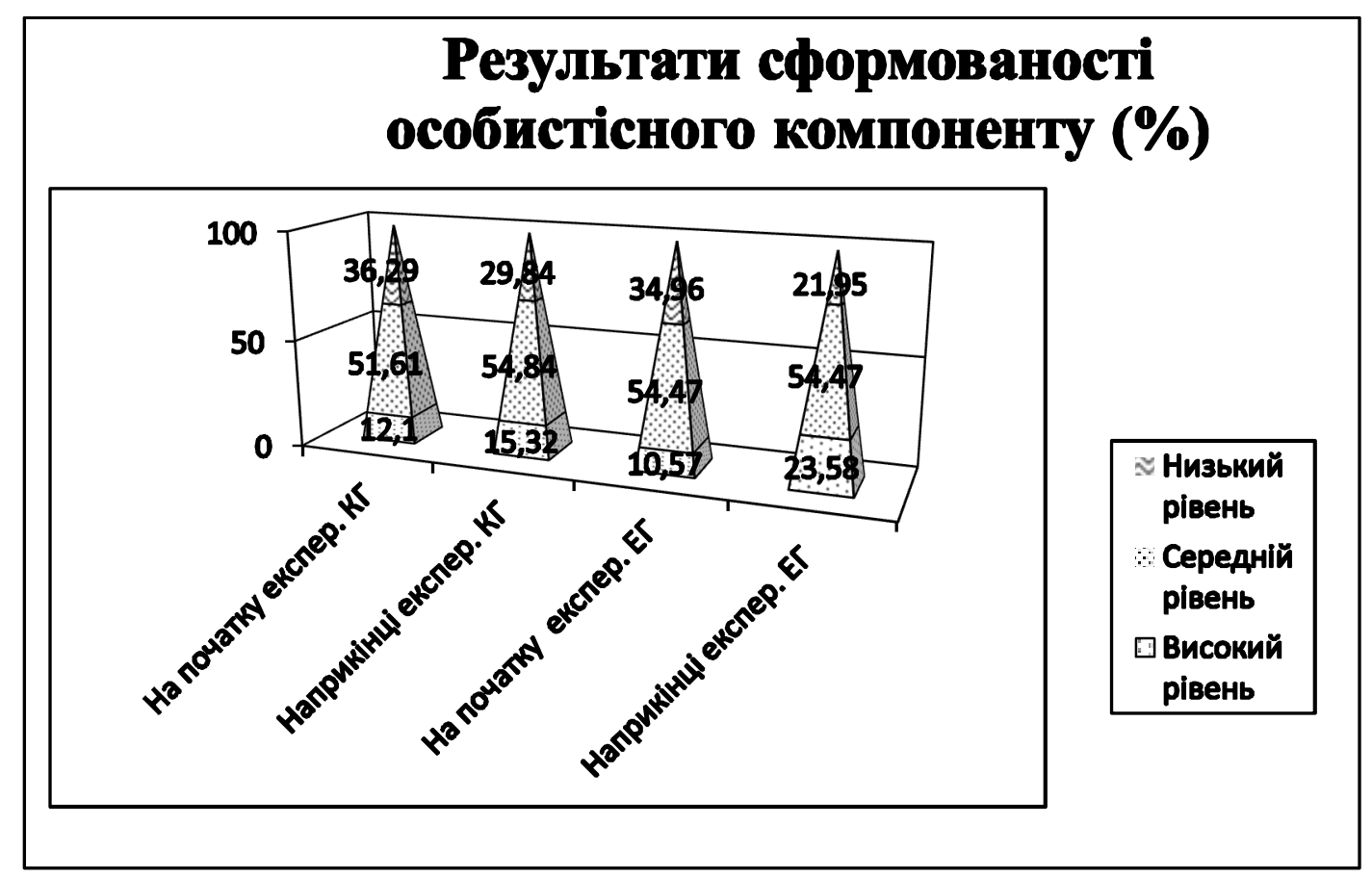

Рис. 1. Результати сформованості особистісного компоненту на початку та наприкінці фрормувального етапу експерименту в КГ та ЕГ

\section{V Висновки}

У процесі узагальнення і систематизації одержаних результатів дослідження [7; 8] спостерігаємо позитивну динаміку рівнів сформованості готовності студентів до професійної діяльності у процесі вивчення фахових дисциплін. Порівнюючи результати формувального етапу, нами визначено, що під час проведення педагогічного формувального етапу відбулися значні зміни за особистісним компонентом готовності. Отже, під час проведеного педагогічного експерименту майбутні молодші медичні спеціалісти ЕГ одержали більш високі результати в порівнянні зі студентами КГ, і відповідно мають вищий рівень сформованої готовності до професійної діяльності. Констатована позитивна динаміка дає підстави вважати, що впровадження педагогічних умов і розробленої моделі здатні суттєво підвищити якість та ефрективність професійної підготовки в медичних закладах освіти. Вважаємо, що наші доробки в контексті використання технології контекстного навчання, формування деонтологічної компетентності й застосування інноваційних інтернет-технологій можна використовувати під час вивчення інших дисциплін у сучасних медичних закладах вищої та фахової передвищої освіти.

\section{Бібліографічні посилання}

1. Проект постанови Верховної Ради України від 18.05.2017 № 6467 (Про Рекомендації парламентських слухань на тему: «Медична освіта в Україні: погляд у майбутнє». База даних [Законодавство України] URL: http://search.ligazakon.ual/_doc2.nsf/link1/DH4ZNOOA.html (дата звернення: 11.05.1020).

2. Акімова О. В., Коломієць А. М., Дудікова Л. В., Остраус Ю. М. Формуваня когнітивної складової професійнокомунікативної культури майбутніх сімейних лікарів засобами інформаційно-освітнього блогу. Інформаційні технологї і засоби навчання. 2020. Том 75, №1. C. 90-107. (WoS). URL: https://journal.iitta.gov.ua/index.php/itt/article/view/3071/1617 (дата звернення: 1.03.2020).

3. Natalia Kalyniuk, Iryna Melnychuk, Andriy Makhnitskyy, Larysa Dudikova, Ruslan Hrynko, Anatolii Halimov, Ihor Bloshchynskyi. Bologna Process and constitutional guarantees of a personal right to education in medical practitioners' training. Dilemas Contemporáneos: Educación, Política y Valores . 2019. T. 7. C. 1-22. URL: http://search.ebscohost.com/login.aspx?direct=true\&profile=ehost\&scope=site\&authtype=crawler\&jnl=20077890\&AN=141222 
807\&h=FgxGGuC6xMHNdRr2g\%2F260Vk3\%2F9JOZeO6qLUciQwT6btQsyueV7rndeec182\%2Ber48P79nr0A0g2rzEFLDhmyB $\mathrm{Eg} \% 3 \mathrm{D} \% 3 \mathrm{D} \& \mathrm{crl}=\mathrm{c}$ (дата звернення: 1.03.2020).

4. Гуревич Р. С., Цехмістер Я. В. та ін. Формування професійної етики майбутніх лікарів-хірургів засобами технології «кейс-стаді». Клінічна хірургія. №7. 2019. (Scopus), URL:https://hirurgiya.com.ua/index.php/journal/article/view/707 (дата звернення: 11.05.1020).

5. The discussions of methodological approaches to pre-occupational training at lyceums as the new philosophy of medical education / Ya. Tsekhmister, Ed. Dei, M. Rudenko. Innovations in Science: The Challenges of Our Time. Hamilton: Accent Graphics Communications \& Publishing. 2018. C. 138-154. URL: http://centresipd.com/pages/191 (дата звернення: 11.05.1020).

6. Optimization of web-application performance / D. O. Kovaliuk, O. Y. Pinaieva, A. Kotyra, \& A. Kalizhanova. Photonics Applications in Astronomy, Communications, Industry, and High-Energy Physics Experiments 2019 (Vol. 11176, p. 1117626). International Society for Optics and Photonics (Scopus). URL: https://www.spiedigitallibrary.org/conference-proceedings-ofspie/11176/1117626/Optimization-of-web-application-performance/10.1117/12.2537163.full (дата звернення: 11.05.1020).

7. Improvement of Learning Outcomes in Educational Process of Intems-Pharmacists using Distance Learning Elements I Larysa Dudikova, Vasyl Pogorilyi, Oleksandr Yakymenko, Serhii Poyda, Borys Koval. Information Technologies and Learning Tools. 2020. T. 76, №2. C. 236-249. (WoS). URL: https://journal.iitta.gov.ua/index.php/itt/article/view/3038 (дата звернення: 11.05.1020).

8. Фрицюк В. А. Синергетичний підхід у підготовці майбутніх медичних працівників до професійного саморозвитку. Збірник наукових праць Національної академії Державної прикордонної служби України. Серія : педагогічні науки. 2019. № 4(12). C. 416-428.

9. Бальдассарре Ф. Сестринское дело в XXI веке: тенденции, проблемы и перспективы (на примере Канады, Италии и Чили). Мед. образование и проф. развитие. 2010. № 2. С. 30-40.

10. Гребеник Ю. С. Особливості підготовки медичних сестер у Великій Британії, США та Україні. Педагогічна компаративістика - якісний вимір освіти зарубіжжя та український контекст : матеріали наук.практ. семінару 5 червня 2014 р., Київ, 2014. С. 133-135.

11. Рядом в трудную минуту: незаменимая и недооцененная профессия медсестры. URL: https://sputnikgeorgia.ru/reviews/20170512/235954375/Miloserdie-kazhdyj-den-medsestry-otmechajut-svoj-prazdnik.html (дата звернення: 11.05.1019).

12. Ернандес Н. А. Особливості вищої медсестринської освіти в Польщі і в Україні. Вища освіта в медсестринстві: проблеми і перспективи: матеріали Всеукраїнської науково-практичної конфреренції. Житомир, 2012. 268 с.

13. Кушніренко Н. Клінічне мислення: чому і як вчать в українських мед вишах - на прикладі ІФНМУ. Аудиторія. 2017. 14 липня.

http://kurs.if.ua/articles/formuvaty_klinichne_myslennya_chomu_i_yak_vchat_v_ukrainskyh_medychnyh_vyshah_na_prykladi _ifnmu_55723.html (дата звернення: 11.05.1020).

14. Кравченко О. Формування профресійної етики майбутніх медичних сестер: американський досвід. Порівняльна профресійна педагогіка. Черкаси, 2012. № 1. С. 82-87.

15. Лавриш Ю. Е. Профресійна підготовка медичних сестер в університетах Канади : автореф. дис. ... канд. пед. наук : 13.00.04. К., 2009. 21 c.

16. Логуш Л. Г. Тенденції розвитку медичної освіти в освітній політиці Європейського Союзу : дис. на здобуття наук. ступеня канд. пед. наук : спец. 13.00.04. Київ, 2016. 239 с.

17. Пікон К. С. Американський досвід організації ступеневої медсестринської освіти. Молодий вчений. 2016. № 12.1. С. 507510.

18. Криза медсестринства в Україні: чи врятує нова концепція? : за матеріалами Медичної газети України. Ваше здоров'я. № 15-16 (від 15.04.2016). С. 8-10.

19. Харлашина Е. В. Профессиональная подготовка среднего медицинского персонала во Франции: система, содержание, технологии : дис. ... канд. пед. наук: 13.00.08. Орел, 2016. 205 с.

20. Тест рефрлексии. Методика диагностики уровня развития рефрлексивности, опросник Карпова А. B. URL: http://psycabi.net/testy/517-test-refleksii-metodika-diagnostiki-urovnyarazvitiya-refleksivnosti-oprosnik-karpova-a-v. (дата звернення: 1.03.2020).

21. Кайдалова Л. Г., Пляка Л. В. Психологія спілкування : навчальний посібник, Харків, 2011. 132 с.

22. Фетискин Н. П., Козлов В. В., Мануйлов Г. М. Социально-психологическая диагностика развития личности и малых групп. М., 2002. С. 15-16.

23. Філоненко М. М. Психологія особистісного становлення майбутнього лікаря : дис ... доктора псих. наук: 19.00.07. Київ, 2016. $425 \mathrm{c}$.

24. ілоненко М. М. Психологія особистісного становлення майбутнього лікаря. Київ, монографія. 2015. 334 с.

25. Шевченко Л. С., Ілясова Ю. С. Використання інноваційних інтернет-технологій у медичних коледжах. Сучасні інформаційні технології та інноваційні методики навчання в підготовці фахівців: методологія, теорія, досвід, проблеми. 3б. наук. пр. Київ-Вінниця, 2019. Вип. 54. С. 148-154.

26. Шевченко Л. С., Илясова Ю. С. Практический аспект реализации контекстного обучения студентов-медиков. Медицинская наука XXI века - взляд в будущее : материалы 67 Международной научно-практической конференции ТГМУ им. Абуали ибни Сино. Душанбе, 2019. Т. 3. С. 333-334 


\section{References}

1. Draft Resolution of the Verkhovna Rada of Ukraine of 18.05.2017 № 6467 (On the Recommendations of the Parliamentary Hearings on the topic: "Medical Education in Ukraine: a look into the future".[Proekt postanovy Verkhovnoi Rady Ukrainy vid 18.05.2017 № 6467 (Pro Rekomendatsii parlamentskykh slukhan na temu: «Medychna osvita v Ukraini: pohliad u maibutnie»]. URL: http://search.ligazakon.ua/l_doc2.nsf/link1/DH4ZN00A.html (accessed 07.09.2020). [in Ukrainian]

2. Akimova O.V., Kolomiets A.M., Dudikova L.V., Ostraus Y.M. 2020. Formation of the cognitive component of professional and communicative culture of future family doctors by means of information and educational blog. Information technologies and teaching aids. [Formuvanya kohnityvnoyi skladovoyi profesiyno-komunikatyvnoyi kul'tury maybutnikh simeynykh likariv zasobamy informatsiyno-osvitn'oho blohu. Informatsiyni tekhnolohiyi i zasoby navchannya]. Volume 75, №1. P. 90-107. (WoS). [in Ukrainian]

3. Natalia Kalyniuk, Iryna Melnychuk, Andriy Makhnitskyy, Larysa Dudikova, Ruslan Hrynko, Anatolii Halimov, Ihor Bloshchynskyi. (2019). Bologna Process and constitutional guarantees of a personal right to education in medical practitioners 'training. Contemporary Dilemmas: Education, Politics and Value. T. 7. S. 1-22.

4. Gurevich R.S., Tsekhmister J.V. and others. (2019). Formation of professional ethics of future surgeons by means of "case study" technology. [Formuvannya profesiynoyi etyky maybutnikh likariv-khirurhiv zasobamy tekhnolohiyi «keys-stadi»]. Clinical surgery. №7. (Scopus). [in Ukrainian]

5. Ya. Tsekhmister, Ed. Dei, M. Rudenko (2018). The discussions of methodological approaches to pre-occupational training at lyceums as the new philosophy of medical education. Innovations in Science: The Challenges of Our Time. Hamilton: Accent Graphics Communications \& Publishing. C. 138-154.

6. D. O. Kovaliuk, O. Y. Pinaieva, A. Kotyra, \& A. Kalizhanova. (2019). Optimization of web-application performance. Photonics Applications in Astronomy, Communications, Industry, and High-Energy Physics Experiments (Vol. 11176, p. 1117626). International Society for Optics and Photonics (Scopus). URL: https://www.spiedigitallibrary.org/conference-proceedings-ofspie/11176/1117626/Optimization-of-web-application-performance/10.1117/12.2537163.full (accessed 07.09.2020).

7. Larysa Dudikova, Vasyl Pogorilyi, Oleksandr Yakymenko, Serhii Poyda, Borys Koval. (2020). Improvement of Learning Outcomes in Educational Process of Interns-Pharmacists using Distance Learning Elements. Information Technologies and Learning Tools. T. 76, №2. C. 236-249. (WoS).

8. Fritsyuk V.A. (2019). Synergetic approach in the preparation of future medical workers for professional self-development. [Synerhetychnyy pidkhid u pidhotovtsi maybutnikh medychnykh pratsivnykiv do profesiynoho samorozvytku]. Collection of scientific works of the National Academy of the State Border Guard Service of Ukraine. Series: pedagogical sciences. № 4 (12). P. 416-428. [in Ukrainian]

9. Bal'dassarre F. (2010). Sestrinskoye delo v XXI veke: tendentsii, problemy i perspektivy (na primere Kanady, Italii i Chili). Med. obrazovaniye i prof. razvitiye. № 2. S. 30-40. [in Russian]

10. Grebenik Yu. S. (2014). Specialties of the training of nurses in Great Britain, the USA and Ukraine. [Osoblyvosti pidhotovky medychnykh sester u Velykiy Brytaniyi, SSHA ta Ukrayini]. Pedagogical Comparative Studies - Yakisny Vimir of Education and the Ukrainian Context: Materials of Science and Practice. seminar 5 worm 2014 p., Kiev, S. 133-135. [in Ukrainian]

11. Ryadom $v$ trudnuyu minutu: nezamenimaya i nedootsenennaya professiya medsestry. URL: https://sputnikgeorgia.ru/reviews/20170512/235954375/Miloserdie-kazhdyj-den-medsestry-otmechajut-svoj-prazdnik.html (accessed 07.09.2020). [in Russian]

12. Hernandez N.A. (2012). Features of higher nursing education in Poland and Ukraine. [Osoblyvosti vyshchoyi medsestryns'koyi osvity v Pol'shchi i v Ukrayini]. Higher education in nursing: problems and prospects: materials of the All-Ukrainian scientificpractical conference. Zhytomyr, 268 p. [in Ukrainian]

13. Kushnirenko N. (2017). Klinichne myslennya: chomu i yak vchat' v ukrayins'kykh med vyshakh - na prykladi IFNMU. Audytoriya. 14 lypnya. URL : http://kurs.if.ua/articles/formuvaty_klinichne_myslennya_chomu_i_yak_vchat_v_ukrainskyh _medychnyh_vyshah_na_prykladi_ifnmu_55723.html (accessed 07.09.2020). [in Ukrainian]

14. Kravchenko O. (2012). Formation of professional ethics of future nurses: the American experience. [Formuvannya profesiynoyi etyky maybutnikh medychnykh sester: amerykans'kyy dosvid]. Comparative professional pedagogy. Cherkasy, № 1. S. 82-87. [in Ukrainian]

15. Lavrysh YU. E. (2009). Profesiyna pidhotovka medychnykh sester v universytetakh Kanady : avtoref. dys. ... kand. ped. nauk: 13.00.04. K., 21 s. [in Ukrainian]

16. Lohush L. H. (2016). Tendentsiyi rozvytku medychnoyi osvity v osvitniy politytsi Yevropeys'koho Soyuzu : dys. na zdobuttya nauk. stupenya kand. ped. nauk: spets. 13.00.04. Kyyiv, 239 s. [in Ukrainian]

17. Picon K. (2016). American experience in the organization of graduate nursing education. [Amerykans'kyy dosvid orhanizatsiyi stupenevoyi medsestryns'koyi osvity]. Young scientist. № 12.1. Pp. 507-510. [in Ukrainian]

18. Kryza medsestrynstva v Ukrayini: chy vryatuye nova kontseptsiya? : za materialamy Medychnoyi hazety Ukrayiny. Vashe zdorov'ya. № 15-16 (vid 15.04.2016). S. 8-10. [in Ukrainian]

19. Kharlashina Ye. V. (2016). Professional'naya podgotovka srednego meditsinskogo personala vo Frantsii: sistema, soderzhaniye, tekhnologii : dis. ... kand. ped. nauk: 13.00.08. Orel,. 205 s. [in Russian]

20. Karpov A.V. Reflection test. Methods for diagnosing the level of development of reflexivity, questionnaire refleksyy. (2012). [Metodyka dyahnostyky urovnia razvytyia refleksyvnosty, oprosnyk Karpova A. V.] URL: http://psycabi.net/testy/517-testrefleksii-metodika-diagnostiki-urovnyarazvitiya-refleksivnosti-oprosnik-karpova-a-v (accessed 07.09.2020). [in Russian]

21. Kaidalova L.G., Plaka L.V. (2011). Psychology of communication: a textbook, [Psykholohiia spilkuvannia : navchalnyi posibnyk]. Kharkiv, 132 p. [in Ukrainian] 
22. Fetyskyn N. P., Kozlov V. V., Manuilov H. M. (2002). Socio-psychological diagnosis of personality development and small groups. [Sotsyalno-psykholohycheskaia dyahnostyka razvytyia lychnosty y malukh hrup]. M., 15-16. [in Russian]

23. Filonenko M. M. (2016). Psychology of personal development of the future doctor. [Psykholohiia osobystisnoho stanovlennia maibutnoho likaria]. Kyiv, 425 p.: Psykh. science doctor author's abstract: 19.00.07.. 425 p. [in Ukrainian]

24. Filonenko M. M. (2015) Psychology of personal development of the future doctor. [Psykholohiia osobystisnoho stanovlennia maibutnoho likaria]. Kyiv, monohrafiia. 334 p. [in Ukrainian]

25. Shevchenko L. S., lliasova Yu. S. (2019). Use of innovative Internet technologies in medical colleges. [Vykorystannia innovatsiinykh internet-tekhnolohii u medychnykh koledzhakh]. Modern information technologies and innovative teaching methods in training: methodology, theory, experience, problems. Kyiv-Vinnytsia. N 54. 148-154. [in Ukrainian]

26. Shevchenko L. S., Yliasova Yu. S. (2019). Practical aspect of realization of contextual training of medical students. [Praktycheskyi aspekt realyzatsyy kontekstnoho obuchenyia studentov-medykov]. Medical science of the XXI century - a look into the future: materials of the 67th International scientific-practical conference of TSMU. Abuali ibni Sino. Dushanbe. T. 3. 333-334. [in Russian]

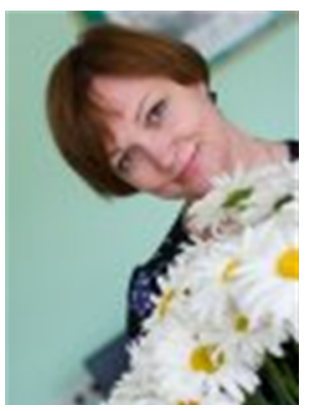

Шевченко Людмила Станіславівна.

Доктор педагогічних наук, професор кафедри інноваційних та інфоормаційних технологій в освіті, Вінницький державний педагогічний університет імені Михайла Коцюбинського,

вул. Острозького, 32, м. Вінниця, Україна, 21001

Тел. 0677328246. E-mail: lysi4801@gmail.com

Shevchenko Ludmila Stanislavivna.

Doctor of Pedagogical Sciences, Professor,

Vinnytsia Mykhailo Kotsiubynsky State Pedagogical University,

Ostrozkoho St., 32, Vinnytsia, Ukraine, 21100.

Тел.0677328246. E-mail lysi4801@gmail.com

ORCID: 0000-0003-4991-4949

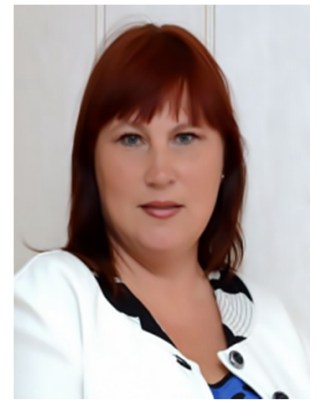

Ілясова Юлія Станіславівна.

Доктор філософії з педагогіки,

Вінницький медичний коледж,

вул. Пирогова, 57, м. Вінниця, 21000.

Тел. 0973326630.E-mail: iyulya72@ukr.net

Iliasova Yuliia Stanislavivna.

$\mathrm{PhD}$ in in Pedagogy, Lecturer,

Vinnytsia Medical Colledge, Vinnytsia, Ukraine

57, Pirogova St., Vinnytsia, 21000, Ukraine

Tel. 0973326630 . E-mail: iyulya72@ukr.net

ORCID: 0000-0003-4570-4426

\section{Citation (APA):}

Shevchenko L. S., lliasova Yu. S. (2020). Experimental verification of formed of the personal component of the readiness medical students for professional activity. Engineering and Educational Technologies, 8 (4), 51-62. doi: https://doi.org/10.30929/23079770.2020 .08 .04 .05

\section{Цитування (ДСТУ 8302:2015):}

Шевченко Л. С., Ілясова Ю. С. Експериментальна перевірка сфрормованості особистісного компоненту готовності студентівмедиків до професійної діяльності / Інженерні та освітні технології. 2020. Т. 8. № 4. С. 51-62. doi: https://doi.org/10.30929/23079770.2020 .08 .04 .05

обсяг cmammi: сторінок - 12; умовних друк. аркушів - 1,738. 